\title{
The Ethics of Labor Immigration Policy
}

\section{Martin Ruhs and Ha-Joon Chang}

\begin{abstract}
This article examines the key ethical questions in the design of labor immigration programs. We propose a two-dimensional matrix of ethical space that isolates a number of different ethical frameworks on the basis of the degree of consequentialism they allow and the moral standing they accord to noncitizens. We argue for the rejection of extreme ethical frameworks and propose criteria that should guide national policymakers in their choice and application of a framework within the ethical subspace of moderate consequentialism and moderate moral standing for noncitizens. To translate these "ethical guidelines" for the design of labor immigration programs into policy practice, we advocate new types of temporary foreign worker programs. In contrast to many existing and past guest worker policies, the programs that we propose would more actively promote the interests of migrant workers and sending countries by more clearly defining, and more effectively enforcing, certain core rights of migrant workers.
\end{abstract}

Recent estimates suggest that, as of 2000, there were around 175 million people living temporarily or permanently outside their home countries, which is about 3 percent of the world population and more than double the number in 1970. Sixty percent of the world's migrants currently reside in the more developed regions (including 56 million in Europe and 41 million in North America), where almost one in every ten persons is a migrant. ${ }^{1}$ With the number of refugees and asylum

For their helpful comments, we would like to thank Manolo Abella, Rainer Bauböck, Thomas Bräuninger, Wayne Cornelius, Clare Fox, David Heer, Jessica Heynis, Robert Holton, Eddie Hyland, Miles Kahler, Alan Kessler, Christian Klamler, Christoph Kuzmics, Phil Martin, Gail McElroy, Robert McLaughlin, Onora O’Neill, Nalini Persram, Thomas Pogge, Carlos Rodriguez, Robert Rowthorn, John Sender, Patrick Taran, Takeyuki Tsuda, Patrick Weil, two anonymous referees, and especially the editors of this journal. Martin Ruhs gratefully acknowledges financial support from the Cambridge European Trust, the Cambridge Political Economy Society Trust, the Center for Comparative Immigration Studies at the University of California-San Diego, and the Policy Institute at Trinity College Dublin. Most of this article was written while Martin Ruhs was a Ph.D. candidate at the Faculty of Economics and Politics, University of Cambridge, and a Visiting Research Fellow at both the Center for Comparative Immigration Studies at the University of California-San Diego, and the Policy Institute at Trinity College Dublin. Ha-Joon Chang wishes to thank the Korea Research Foundation for its research support through the BK21 program at the Department of Economics, Korea University, where he was a Visiting Research Professor when the manuscript was completed.

1. United Nations Population Division 2002. 
seekers in 2000 standing at about 12 million and 1 million, respectively, ${ }^{2}$ the vast majority of the world's migrants are migrant workers and their families.

While these estimates remain controversial (especially because of the difficulties associated with estimating the number of illegal migrants), it is clear that virtually all countries host at least some noncitizen residents. There is also evidence suggesting that the number of countries significantly affected by immigration has risen over the past three decades. According to United Nations (UN) estimates, in 1965 the forty-four countries with the largest number of international migrants accounted for 90 percent of the global stock of migrants. ${ }^{3}$ By 2000, the number of countries accounting for that share had increased to fifty-nine.

Consequently, immigration policy - in addition to remaining important in countries with a relatively long history of hosting noncitizens-has recently also become important in many countries that used to be net emigration countries and had little immigration in the past (such as Ireland, Italy, and Spain). Much-publicized examples of ongoing debates on labor immigration include the current discussions about proposals for a new guest worker program for Mexican farm labor in the United States, the recent discussions in the European Union (EU) about when to grant citizens of the ten Accession Countries freedom of employment within the enlarged EU, recent proposals to radically reform Germany's policies for both permanent and temporary immigration, and the controversies surrounding the admission and employment of high-technology workers in practically all high-income countries.

Despite (or perhaps because of) the rising number of journalistic as well as academic contributions, labor immigration debates remain particularly heated, muddled, and confused. Why is this?

The most important source of this problem, we argue, is the distinct nature of international labor migration, which, in contrast to international trade and capital flows, involves the cross-border movement of people, who lay claim to certain rights vis-à-vis the host state and their fellow residents. This means that labor immigration policymakers need to decide not only on the number and type of noncitizens to be admitted, but also on the rights that noncitizens are to be granted after admission. Despite the important and distinct role of rights as a policy parameter, there is a general reluctance and apparent inability among the participants in the debate to explicitly state, justify, and critically discuss the ethical points of view underlying their arguments. This inability makes it impossible to conduct a comprehensive and balanced debate.

Given this state of affairs, the primary objective of this article is to examine the key ethical issues in the design of labor immigration programs and thereby provide a framework for the comprehensive discussion of such programs. A second-

2. United Nations High Commissioner for Refugees 2002.

3. Zlotnik 1998 . 
ary objective is to explore the implications of this analysis of the ethical issues in labor immigration policy for the design of labor immigration programs in practice.

It should be noted that the present article specifically focuses on labor immigration policy, as opposed to "humanitarian" immigration policies that are concerned with refugees and asylum seekers. Of course, we need to add that the very distinction between these two categories is itself a key policy issue-as evidenced by the frequently heard argument that we need to sort out "bogus asylum seekers" or "disguised economic migrants" from "genuine refugees."

The article is divided into five main sections, which are as follows. First, we establish the important role of migrant workers' rights as a key policy parameter in the design of labor immigration programs. We then discuss the consequences of international labor migration for the migrant-receiving country, the migrant-sending country, and migrants themselves. The third section proposes a two-dimensional matrix of ethical space, which isolates a number of different ethical frameworks on the basis of the degree of consequentialism they allow and the moral standing they accord to noncitizens. Next, we explore the implications of some of these frameworks for the design of labor immigration policy. Finally, we discuss the implications of our analysis for the ethical considerations necessary in the design of labor immigration programs in practice.

In addition to providing a framework for discussing labor immigration policies in a structured and informed manner, our article argues for the rejection of extreme ethical frameworks and proposes criteria that should guide national policymakers in their choice and application of a framework within the ethical subspace of moderate consequentialism and moderate moral standing for noncitizens. To translate these "ethical guidelines" for the design of labor immigration programs into policy practice, we advocate new types of temporary foreign worker programs. In contrast to many existing and past guest worker policies, the programs we propose would more actively promote the interests of migrant workers and sending countries by more clearly defining, and more effectively enforcing, certain core rights of migrant workers.

\section{Migrants' Bundles of Rights as a Policy Parameter}

The first step toward a sensible discourse on any policy is to clearly and fully identify all its policy parameters. Although this seems like an obvious statement, the existing discussion of labor immigration policy has often been hampered by a conspicuous absence of the acknowledgment, definition, and consideration of all relevant policy parameters.

The great majority of contributions to the economic analysis of labor immigration assume that the cross-border movement of labor may be analyzed in the same way in which one analyzes the flow of capital or goods. Policy recommendations are accordingly formulated in terms of the quantity and the type (mainly the skill level) of foreign workers, as determined by their perceived impact on economic 
efficiency and equity in the host country. While analytically convenient, such analysis of labor immigration misses the critical point that cross-border movements of people are accompanied by the granting of rights (however minimal) to the new entrants. Therefore, labor immigration policymakers need to decide not only on the number and type of noncitizens to be admitted, but also on the "bundles of rights" that noncitizens are to be granted after admission.

Even the most cursory review of citizens' and noncitizens' rights around the world suggests that the various legal categories of each country's residents-such as illegal alien residents, short-term alien residents, long-term alien residents, and citizens - are entitled to distinct bundles of rights, which differ in the number and scope of rights that they contain. For example, an illegal migrant worker's bundle of rights usually includes only very minimal rights, such as the most basic human rights to life and emergency medical care. Most countries do not include the right to free movement within the national labor market in a temporary worker's bundle of rights, while permanent residents usually do not face such restriction. Permanent residents generally do not have the right to vote, which is usually reserved for citizens only. And so on.

Importantly, available bundles of rights do not only differ between various groups of residents within countries, but also between similar groups across countries. This is especially true for temporary foreign workers. For example, unskilled temporary foreign workers in Switzerland and the United States enjoy the (conditional) right to change their status to permanent residents, while guest workers in Kuwait and Singapore do not. To give another example, in Singapore, unskilled temporary migrant workers (so-called nonresident foreigners) do not have the right to marry, or cohabit with, a Singaporean citizen or permanent resident. Female nonresident workers are also required to undergo mandatory pregnancy tests every six months, with the threat of immediate deportation in the case of a positive test result. These restrictions do not apply to, say, unskilled temporary workers in Ireland and the United States, where the birth of a child to an alien resident (including illegal residents) gives the child the right to citizenship.

The examples could go on, but the point we make here should be clear: migrants' bundles of rights differ both within and across countries and thus constitute an empirically relevant policy parameter. Any analysis or discussion that fails to explicitly consider migrants' bundles of rights thus fails to address a core component of labor immigration policy. There are at least two more reasons for explicitly including rights in the analysis of labor immigration-the potential conflict between migrants' rights and natives' rights, on the one hand, and the issue of national identity on the other.

The impact of immigration on the conventional outcome parameters in economic analysis, namely economic efficiency and equity, critically depends on the bundles of rights which migrant workers hold. For example, whether or not noncitizen residents hold such rights as the right against discriminatory taxation, the right to free access to public services (such as public hospitals and schools), the right to unemployment benefits, and the right to free movement in the labor mar- 
ket, is likely to significantly influence the impact of immigration on national income, the fiscal balance, wage and employment outcomes for citizen workers, and income distribution. Any analysis of the impact of immigration on efficiency and distribution in the host economy that fails to take migrant workers' bundles of rights into account is, therefore, at best ambiguous and at worst misleading.

One may take the argument a step further and suggest that a comprehensive impact analysis should also consider the effects of extending rights to migrant workers on the rights of citizens. In other words, citizens' bundles of rights become an additional outcome parameter for labor immigration policymakers. There are, in principle, three different ways in which the extension of rights to noncitizens may affect citizens' rights.

First, conferring certain rights on noncitizens may simply infringe upon the existing rights of citizens. For example, granting noncitizens the right to free movement within the labor market eliminates a citizen's right to preferential access to the national labor market. ${ }^{4}$

Second, extending certain rights to noncitizens may (positively or negatively) affect the value of the (corresponding or other) rights of citizens. ${ }^{5}$ For example, it could be argued that granting noncitizens the right to vote reduces the value of the corresponding right of a citizen, whose vote now makes less of a difference. Similarly, granting noncitizens the right to own certain types of property, such as land, may adversely affect the corresponding right of a citizen, who then needs to compete with noncitizens in the market for land and is thus likely to have to pay a higher price. For yet another example, extending the right to certain social security benefits, such as free public health care, to noncitizens may adversely affect the corresponding right of a citizen, who may then have to wait longer before receiving medical treatment unless the capacity of the medical system is increased. On the other hand, it has been argued that when effective control of the border is economically and politically too costly, legalizing illegal foreign workers is in the interest of the citizens, because migrant workers with more rights are less likely to undercut citizens in terms of wages and working conditions. Trade unions in Italy, Spain, and France have thus recently undergone a turnaround in their approach to illegal immigration and are now arguing in favor of, rather than against, giving already-resident illegal foreign workers more rights. ${ }^{6}$

Finally, other rights, such as the right to silent prayer or the right to privacy, may not have such features; that is, an increase in the number of people with that right does not affect the value of, or infringe upon, the corresponding right of citizens. ${ }^{7}$

4. See, for example, the discussion in Weinstein 2001.

5. For a discussion of the alleged "devaluation" of American citizenship, see Schuck 1998; also see Jacobsen 1996.

6. For a recent discussion of this issue, see Watts 2000.

7. One may argue, however, that increasing the number of holders of the right to privacy may adversely affect another right, namely, the right to safety. This issue has become especially relevant since the 2001 terrorist attacks in the United States. 
The second reason to explicitly incorporate rights into our analysis of labor immigration policy is that such policy is not only driven by considerations of economic efficiency and distribution, but also by a concern for what may be loosely called "national identity," which is understood as the shared set of beliefs and values of a country's residents. ${ }^{8}$ While the importance of national identity as a determinant of immigration policy varies from one country to another, there are a number of countries (such as Japan and Korea) in which the preservation of national identity (or more specifically, cultural homogeneity) has been explicitly mentioned as a major factor determining immigration policy. Before World War II, the United States preferred northern European Protestants to other groups for the same reason. Before 1972, Australia had the White Australia policy.

As we will discuss later in this article, the impact of immigration on national identity is likely to be time- and country-specific. It is clear, however, that the determinants of this impact include not only the number and type of foreign workers, but also their potential for economic, social, cultural, and political integration or assimilation. The latter is critically influenced by the bundles of rights that migrant workers hold. Migrant bundles that are similar to citizen bundles may enable foreign workers (and their dependants) to integrate more easily into the community of resident citizens. At the same time, however, such bundles may also empower foreigners to more strongly influence and change the nature and structure of the citizen community.

The degree to which such integration and empowerment of resident foreigners are desirable depends on how citizens "see themselves," that is, how citizens define and value the preservation of their present collective national identity. For example, national communities with strong cultural (including religious) unity may view foreigners with different cultural backgrounds as a threat to their cultural homogeneity. Similarly, national communities with a strong preference for emphasis on individual autonomy and freedom may consider the presence of foreigners with less tolerant attitudes a threat to these ideals, which in their view define their identity. Countries that strive to become more cosmopolitan or culturally diverse, however, may well view immigration as a means of achieving such a change of national identity (as far as the immigrants accept such diversity).

In any case, whatever the conception of national identity, it is clear that it is an important and empirically relevant outcome variable in immigration policy, and that it is critically influenced by the specific rights that migrant workers hold.

In this section, we have shown why it is necessary to take explicit account of rights in the analysis of labor immigration. Labor immigration programs may thus be classified according to their mechanisms for regulating (1) the number of migrant workers admitted, (2) the selection of migrant workers, and (3) the bundles

8. It also needs to be added that considerations of national identity are often conflated with issues of public order and national security more generally. Again, the latter have gained in importance since the 2001 terrorist attacks. 
of rights extended to migrant workers after admission. Formulating a desirable labor immigration policy, then, essentially involves finding desirable values for these three policy parameters. ${ }^{9}$

It should be noted that the underlying assumption of this perspective is that countries are capable of controlling immigration and thus deciding on these parameters. ${ }^{10}$ We thus assume that the presence of illegal migrants indicates that the host country has, at least to a certain extent, chosen to tolerate their presence.

\section{What Are the Consequences of International Labor Migration?}

In order to identify desirable values for the three policy parameters discussed in the previous section, labor immigration policymakers must first assess the impacts of various (combinations of such) parameter values on a suitably defined social objective function.

One immediate problem is that there has been no agreement on how exactly the various outcome parameters should enter a society's social objective function. The existing literature on the consequences of international labor migration has thus evolved into a patchwork of contributions on particular issues, using various methodologies, rather than a coherent literature within a uniform framework of analysis. To organize and discuss some of the more important contributions, it is useful to distinguish between studies that are concerned with the consequences of migration for nonimmigrants in the receiving country, nonemigrants in the sending country, and migrants themselves. Table 1 lists the relevant outcome parameters for each group, and will inform the way we organize our discussion in the rest of the section. ${ }^{11}$

\section{Consequences for the Receiving Country}

Despite the recent mushrooming of studies of labor immigration, the current understanding of the actual effects of immigration on economic efficiency, distribution, national identity, and citizens' bundles of rights remains rather limited.

9. Of course, the three policy parameters may, in some cases, be interdependent. For example, some countries may find the large-scale employment of foreign workers in their interest only if the rights of the admitted foreign workers can be severely restricted. The employment of foreign workers in the oil-rich Persian Gulf states is a good case in point.

10. For persuasive rebuttals of the popular argument that Western host countries are losing control over immigration, see Freeman 1995; and Joppke 1998.

11. Note that, at this point, we are not concerned, and do not make any assumption, about the receiving country's social objective function, which may include any subset of the ten parameters in Table 1 . The weighing of parameters is discussed in the following section. 
TABLE 1. Outcome parameters in the analysis of the consequences of international labor migration

\begin{tabular}{llll}
\hline & $R C$ & $S C$ & $M$ \\
\hline Economic efficiency & $\mathrm{x}$ & $\mathrm{x}$ & $\mathrm{x}$ \\
Distribution & $\mathrm{x}$ & $\mathrm{x}$ & \\
National identity & $\mathrm{x}$ & $\mathrm{x}$ & \\
RC citizen's bundle of rights & $\mathrm{x}$ & & \\
SC citizen's bundle of rights & & $\mathrm{x}$ & \\
Migrant's bundle of rights & & & $\mathrm{x}$ \\
\hline
\end{tabular}

Note: $\mathrm{RC}=$ Receiving Country; $\mathrm{SC}=$ Sending Country; $\mathrm{M}=$ Migrants.

In terms of welfare analysis, studies based on the standard, partial-equilibrium welfare model suggest that immigration increases, and significantly redistributes, national income from citizen workers to capital owners. Borjas's back-of-theenvelope calculations of the welfare effects of immigration on the U.S. economy as a whole (assuming a one-region aggregate labor market) suggest that in the mid-1990s, the prevailing level of immigration increased gross domestic product (GDP) by 0.1 percent, raised capital income by 2 percent of GDP, and lowered labor income by 1.9 percent of GDP. ${ }^{12}$ On the other hand, analysis with general equilibrium models suggests that the impact of immigration (on its current scale) on citizen welfare and its distribution may be rather small. ${ }^{13}$

The general picture that emerges from empirical labor market studies is that the impact of immigration on the labor market outcomes for citizens is only minor, given the present scale of immigration. ${ }^{14}$ It has been recently pointed out, however, that there is a general tendency in these empirical studies to treat particular labor markets as closed and to ignore the potential immigration-induced outmigration of citizens, which would increase labor supply (and thus affect the labor market outcomes for nonmigrants) in other regions. The immigration-migration nexus may therefore transmit the effects of immigration away from the immigrant destination to the final destinations of citizen out-migrants. ${ }^{15}$ Existing empirical studies of this nexus have been relatively recent, have been confined to the United States, and show conflicting results. ${ }^{16}$

12. Borjas 1995. In a more recent paper, however, Borjas argues that the efficiency gains from immigration are magnified when estimated in the context of an economy with regional differences in marginal product, rather than in the context of a one-region aggregate labor market. See Borjas 2001.

13. See, for example, Trefler 1997.

14. See, for example, Bean et al. 1988; Card 1990; Hunt 1992; Pope and Withers 1993; and Roy 1997.

15. Walker et al. 1992.

16. See, for example, Filer 1992; Walker et al. 1992; Wright et al. 1997; Borjas, Freeman, and Katz 1997; and Card 2001. 
The findings of studies of the effects of immigration on the welfare state are equally mixed. For example, according to a study by Fix and Passel, immigrants in America pay more taxes and generate more government revenue than they create costs. ${ }^{17}$ In contrast, Espenshade and King provide evidence that the positive fiscal effects of immigration may be reversed at the local government level. ${ }^{18}$ In their surveys of the relevant literature, Stalker ${ }^{19}$ and Weber and Straubhaar ${ }^{20}$ conclude that no coherent picture emerges.

Despite (or perhaps because of) this state of the literature, there appears to be somewhat of a "consensus" that the economic impact of immigration is, in all likelihood, only marginal, and most likely marginally positive.

To us, this conclusion is premature and unwarranted, given what we know about the methodological limitations and empirical gaps in the existing literature. For example, the critical relationship between immigration and technical change (that is, whether the supply of cheap immigrant labor retards labor-saving technological progress) has so far, to the best of our knowledge, not been the subject of empirical study and thus remains obscure. Also, there is no reason to expect that the assumptions of general equilibrium models are met in the real world, not even in the long run. Similarly, as illustrated by the recent "discovery" of the potential transmission of local labor market impacts to the national labor market, there is also no reason to assume that existing studies have accounted for all, or even the most important, channels of impact. ${ }^{21}$

We maintain that it would be surprising indeed if labor immigration had only a marginal impact on the receiving economy. Instead, provided that the number and share of foreign workers in the national labor force are significant, the economic consequences of immigration are more likely to be rather significant, especially when the economy is clearly at a disequilibrium point. For example, it is clear that foreign workers played a major role in fueling Europe's post-World War II economic growth by holding down wages and maintaining high rates of profit, investment, and growth. ${ }^{22}$ On the other hand, there may also be circumstances under which immigration, in one way or another, has significant adverse economic impacts on (at least certain local economies of) the receiving country. For example, where migration is "fiscally" induced by differences in social entitlement programs, mass immigration may have severely negative effects on the welfare recipients in the receiving country. ${ }^{23}$

17. Fix and Passel 1994.

18. Espenshade and King 1994.

19. Stalker 1994.

20. Weber and Straubhaar 1996.

21. For another good example, a recent study by Davis and Weinstein considers the terms of trade effects between the United States and the rest of the world (which had hitherto been largely excluded from the analysis of labor immigration) within a Ricardian framework to estimate that, in 1998, the combination of labor immigration and net capital inflows cost the US $\$ 27$ billion, or 0.8 percent of GDP. See Davis and Weinstein 2002.

22. For a discussion, see Kindleberger 1967.

23. For a discussion of this problem, see Sykes 1995. 
The consequences of immigration for national identity may be complex and dependent on how citizens define their "imagined" 24 collective identity. Jordens discusses how, after it had abandoned the "White Australia" policy, the increase in non-European immigration has been a main factor in Australia's transformation from a society that saw itself as essentially British in culture and ethnicity to one that is beginning to define itself by its cultural and ethnic diversity. ${ }^{25}$ In contrast, French scholars continue to debate why and how national cultural norms have suppressed the emergence of diverse immigrant cultures, despite the significant inflow of foreigners, especially from Northern Africa. ${ }^{26}$

Finally, in light of the fact that there are very few empirical studies on this matter, it is difficult to say anything concrete on the impact of immigration on citizens' bundles of rights, but we conjecture that it is likely to be much more significant than what the meagre existing empirical research on this issue suggests.

\section{Consequences for the Sending Country}

Although research on the consequences of international labor migration for sending countries began earlier than that on consequences for receiving countries, the literature on sending countries is now much smaller than that on receiving countries. Studies of the economic effects of emigration generally focus on the production and employment effects of emigration, the effects of remittances, and the impact on the fiscal balance.

The empirical evidence on the output and employment effects of emigration is mixed. Nayyar concludes that, mainly because of the small share of emigrants in India's total labor force, the output and employment effects of both permanent and temporary emigration from India have been negligible. ${ }^{27}$ However, India is a special case, as it has an oversupply of highly skilled, specialist workers. ${ }^{28}$ The emigration of skilled workers ("brain drain") from other countries with a limited supply of such workers can have serious adverse production impacts on the sending countries (that invested in their training and skill). For example, between 1960 and 1987, Sub-Saharan Africa alone is estimated to have lost about 30 percent of its highly skilled manpower, mainly to the European Community (EC). ${ }^{29}$

The effects of remittances have been found to be mixed-both in theory and practice. Remittances may benefit the sending country through, inter alia, an easing in foreign exchange constraints and through their role as a source of capital

24. On the notion of nations as "imagined communities," see Anderson 1983.

25. Jordens 1997.

26. See, for example, Noiriel 1996.

27. Nayyar 1994.

28. In 1987, India turned out 220,700 graduates and postgraduates in science, engineering, medicine, and agricultural sciences, at a time when 1.2 million of its 3.8 million pool of scientifically trained people were out of work. See Stalker 1994.

29. Stalker 1994. 
formation. However, they tend to be unpredictable and may be spent on luxury consumer goods, which can increase demand, increase inflation, and push up wage levels. ${ }^{30}$ The majority of empirical studies find that most remittances are spent on imported consumer items and conspicuous consumption in general. ${ }^{31}$ A more recent review by Taylor, however, paints a somewhat more positive picture, citing a study which found that, because of national multiplier effects on income, employment, and production, for every dollar sent or brought into Mexico by migrants working abroad, Mexico's gross national product (GNP) increased by about $\$ 2.69$ to $\$ 3.17$, depending on which household groups in Mexico received the remittances. ${ }^{32}$

Emigration also impacts the fiscal balance of the sending country, by reducing its tax revenues. A recent study of the fiscal impact of Indian emigration to the United States found that the net fiscal loss associated with the U.S. Indian-born resident population ranged from 0.24 percent to 0.58 percent of Indian GDP in $2001 .^{33}$

The overall economic effects of emigration on the sending country thus appear to be ambiguous, although the evidence may be interpreted to suggest that the emigration of unskilled labor is likely to be beneficial (as production and fiscal effects are likely to be minor and the benefits from remittances may be significant) while that of skilled labor is often not. This conclusion is also supported by many sending countries' continued efforts to convince receiving countries to open their borders to more unskilled workers. The best examples may be Mexican President Vincente Fox's efforts to significantly liberalize migration flows from Mexico to the United States and the developing countries' efforts to include the issue of international labor migration in the agenda of the World Trade Organization (WTO) - in particular the General Agreement on Trade in Services (GATS).

Finally, there is little doubt that large-scale emigration (such as that from Mexico and the Philippines) has an impact on national identity in sending countries, mainly through imported consumer goods purchased with remittances and through the return of emigrants who have acquired some of the receiving country's values and habits. In some cases, emigrants may also exert considerable influence on national politics in their countries of origin, as suggested by the fact that Los Angeles was an official stop during President Fox's presidential campaign. ${ }^{34}$ It is easy to imagine that the political influence of emigrants abroad may also affect the bundles of rights of nonemigrants in the sending countries, although this has, to the best of our knowledge, never been explicitly studied.

30. For an extensive review, see Russel 1986.

31. For reviews see Chandavarkavar 1980; and Taylor et al. 1996.

32. Taylor 1999, citing Adelman and Taylor 1990.

33. Desai, Kapur, and McHale 2001.

34. For a discussion of these issues, see Fitzgerald 2000. 


\section{Consequences for Migrants}

By revealed preference, the consequences of voluntary migration are likely to be positive for most labor migrants. Rational and fully informed migrants would not migrate (or would return home), if there were no (more) net gains from moving to (or staying in) the receiving country. The problem, of course, is that imperfect information about employment and living conditions in the receiving countries is the norm, rather than the exception.

It is well known that international labor migration frequently takes place within an environment of exploitation and what is widely seen as the violation of migrant workers' basic human rights. ${ }^{35}$ Many migrant workers, especially unskilled workers, are accorded rights by the receiving country that are fewer and much more narrowly defined than the rights they enjoyed in their home countries.

It thus appears as though many migrant workers face a trade-off between economic betterment and restrictions of their rights. The latter often contribute to what are likely to be substantial psychological costs of migration, associated with leaving one's home and possibly also (temporarily) separating from one's family.

\section{What Consequences Should Policymakers Care About, and for Whom?}

Having discussed the consequences of international labor migration, the multitude of outcome parameters in each group (nonimmigrants, nonemigrants, migrants) demands that one find a way to weigh the various parameters in the policymaker's social objective function. ${ }^{36}$ To identify and disentangle the key ethical issues in this inherently normative exercise ${ }^{37}$ it is useful to think of the assignment of weights to the outcome parameters in Table 1 as a process that involves two steps. For the first step, the policymaker needs to decide on the weights assigned to the outcome parameters relevant to his/her own (receiving) country (that is, the outcome parameters listed in the receiving country's column in Table 1). To discuss the ethical bases for making this decision, it is necessary to address the more general (and much discussed) question of what degree of "consequentialism" should be employed in the evaluation of alternative policy designs.

As the second step, the policymaker needs to assign weights to outcome parameters pertaining to the sending country and the migrants themselves (as listed in the respective columns in Table 1). The underlying ethical question concerns the

35. For a discussion, see Taran 2000.

36. One could argue that the process of assigning weights to the various outcome parameters in Table 1 defines the "national interest." This framework for defining the national interest would be in line with Nye, who suggests that "global interests can be incorporated into a broad and far-sighted concept of the national interest." See Nye 2002, 236.

37. For an overview of contemporary theories of political philosophy, see, for example, Kymlicka 2002. 


\section{Minimally consequentialist ("rights-based")}

Strictly consequentialist ("consequentialist")

FIGURE 1. Spectrum of consequentialism in moral theories

"moral standing" to be accorded to noncitizens. By considering this second ethical question, we firmly situate ourselves among those who allow for the possibility that ethics matter in a country's dealings with foreigners, and in the study of international relations more generally. ${ }^{38}$

\section{What Degree of Consequentialism?}

An action (including policy) may be described by its consequences (or outcomes) and by the means (or processes) by which the consequences are generated. Accordingly, the ethical evaluation of an action may concern itself with either consequences or processes, or with both.

Different ethical theories disagree on the extent to which assessments of consequences and processes should enter the overall ethical evaluation of an action. As suggested by Figure 1, the underlying "degree of consequentialism," that is, the degree to which the ethical evaluation is made in terms of outcomes (ends) rather than processes (means), may be used to locate moral theories along a spectrum that is bound by a minimally consequentialist position at the lower end, ${ }^{39}$ and a strictly consequentialist position at the upper end. ${ }^{40}$

The theory that probably comes closest to being "minimally consequentialist" is Robert Nozick's version of libertarianism. ${ }^{41}$ In Nozick's world, rights are simply "side constraints" on the actions of individuals who may otherwise do as they wish. ${ }^{42}$ The policy imperative for the "minimal state" that Nozick advocates is thus to protect individuals' rights by protecting all its citizens against violence,

38. For a discussion of the role of ethics in international relations, see, for example, Nye 2000; and Cohen 1984.

39. This implies that we assume that even those arguments commonly known as "rights-based" have some minimal concern for consequences. For a discussion of this point, see Chang and Rowthorn 1995.

40. Note that the terms "rights-based" and "consequentialist" in this section, and the terms "nationalism" and "cosmopolitanism" in the following section, are simply used for linguistic convenience, indicating the underlying degree of consequentialism (rights-based versus consequentialist) and moral standing extended to noncitizens (nationalism versus cosmopolitanism). Our usage of these terms does not necessarily reflect or correspond with the meaning given to these concepts in the broader literature.

41. Nozick 1974.

42. Ibid. The idea of rights as side constraints holds that the rights of others determine the constraints upon an individual's actions. In Nozick's theory, an individual's rights must not be violated for the sake of protecting someone else's rights or some greater social good. 
theft, and fraud, and to ensure the enforcement of contracts. ${ }^{43}$ It follows that policies are to be evaluated only in terms of their consequences for individuals' rights, ${ }^{44}$ with little or no regard for their consequences for individuals' well-being or for individuals' collective interest as a community. The main difficulty with this approach is that there is no universal hierarchy among conflicting rights, such that the policymaker needs to decide which rights should be given priority. ${ }^{45}$

At the other end of the spectrum, strict consequentialism is defined as the extreme proposition that an action is to be evaluated in terms of its consequences alone, and therefore, that an action is permissible if there is no alternative with "better" consequences, however measured. ${ }^{46}$ Classical utilitarianism is an example of a strictly consequentialist position, in which the objective of a just society is to achieve the greatest net balance of satisfaction summed over all its members. ${ }^{47}$ It is implied that the consequences justify the means of private action and public policy.

To be sure, if all ethical theories were to be situated along a one-dimensional spectrum of consequentialism, most of them would be found somewhere in between the two extremes. For example, it may be plausibly argued that of the two Rawlsian principles of justice, the "priority of liberty principle" is a nonconsequentialist principle, while the "difference principle" is consequentialist in nature (as it makes the consequence for the distribution of welfare an ethically permissible standard for policy evaluation). ${ }^{48}$ Similarly, by considering freedom as the end and primary means of development, Amartya Sen advocates a partly consequentialist theory that "can take note of, inter alia, utilitarianism's interest in human well-being, libertarianism's involvement with processes of choice and the freedom to act and Rawlsian theory's focus on individual liberty and on the resources needed for substantive freedoms." 49

The desirable degree of consequentialism in the ethical evaluation of public policies (or moral judgment of private action) has, of course, been a much-debated

43. Ibid., 26.

44. To avoid confusion, it is worth spelling out that a minimally consequentialist position is concerned with consequences, but only with consequences for individuals' rights (as means of actions), and not so much with consequences for the outcomes (or ends) for individuals or communities.

45. For a discussion, see Chang 2002.

46. Compare Hausman and MacPherson 1993. Of course, the operationalization of this principle requires that consequences be defined and, if there are potentially competing objectives (such as, in some cases, economic efficiency and income distribution), suitably weighted.

47. See, for example, Sidgwick 1908.

48. Rawls's concept of "justice as fairness" is encapsulated in his two famous principles of justice: (1) Each person has an equal right to a fully adequate scheme of equal basic rights and liberties, which scheme is compatible with a similar scheme for all ("Priority of Liberty Principle"); and (2) Social and economic inequalities are to satisfy two conditions: first, they must be attached to offices and positions open to all under conditions of fair equality of opportunity; and, second, they must be to the greatest benefit of the least advantaged members of society ("Difference Principle"). See Rawls 1985, 227.

49. Sen 1999,86 . 
problem in moral philosophy. ${ }^{50}$ It is not our intention to take a position in this debate, or to critically discuss some of the arguments in favor of or against any particular degree of consequentialism. We merely want to point out that the design of labor immigration policy, or more generally any argument on labor immigration, is necessarily based-either explicitly or, as has been the case more often, implicitly-on an underlying ethical framework that is characterized by a specific degree of consequentialism, as derived from a particular stance in the rights versus consequences debate. The implications of the various degrees of consequentialism for the design of labor immigration policy are discussed in the fourth section of this article. However, we must first discuss the second and equally important notion of "moral standing."

\section{What Moral Standing for Noncitizens?}

Having decided on the degree to which consequences should inform the design of a labor immigration program, the policymaker needs to decide for whom consequences should be taken into account. In other words, should the policymaker only consider the consequences of immigration for citizens, or should he or she also consider the consequences for migrants and the nonemigrant citizens of the sending country? Furthermore, if the policymaker takes into account the consequences for noncitizens, should the consequences for citizens and noncitizens be given equal weights? If not, what should determine the degree to which the policymaker lets the consequences for noncitizens influence the design of the labor immigration program?

The answers to these questions depend on the degree of "moral standing" that the national policymaker accords to noncitizens. Most discussions of immigration policy, and indeed most contributions to moral philosophy, tacitly assume that the national policymaker accords full moral standing to citizens only. Discussions of the moral standing of noncitizens are scarce and frequently avoided. We argue, however, that a comprehensive assessment of how consequences should affect labor immigration policy must include an explicit discussion of the moral standing of noncitizens.

As a first step in that direction, it is necessary to acknowledge that, as with degrees of consequentialism in moral theories, there is a spectrum of degrees of moral standing that the national policymaker may extend to noncitizens. This spectrum is bound by small but positive epsilon at the lower end, and $1-\varepsilon$ at the upper end, as suggested by Figure 2.

We exclude the cases of no (or zero) moral standing and full moral standing for noncitizens as unrealistic and untenable positions. The former would imply that the country does not treat noncitizens as human beings, while the second makes the concept of citizenship meaningless.

50. See, for example, Scheffler, ed. 1998. 


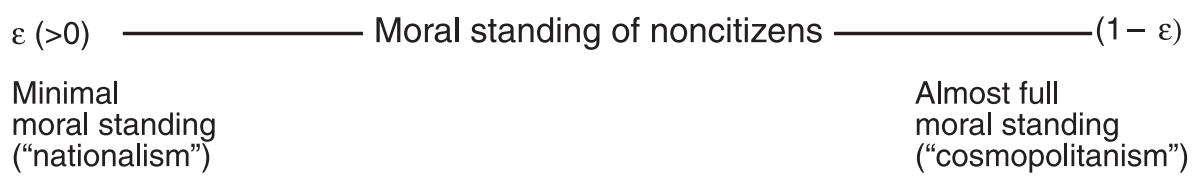

FIGURE 2. Spectrum of moral standing of noncitizens

Advocates of a minimal moral standing for noncitizens frequently employ what Caney calls the "negative arguments from anarchy." 51 This argument comes in three versions, suggesting that due to (1) the absence of an international community that defines and enforces rights and duties, or (2) the lack of significant cooperation among nation-states, or (3) the lack of international cooperation motivated by cosmopolitan ideals, nation-states are under no obligation to include ethical considerations in their dealings with foreigners. A more positive argument for according a low moral standing to noncitizens suggests that it is a moral duty for a nation to follow the "national interest" (narrowly understood as the promotion of the interests of citizens only) in its dealings with other nations. ${ }^{52}$

In contrast, those who believe in maximal (almost full) moral standing for noncitizens believe that there is a set of (very comprehensive) universal rights to which everyone is entitled, regardless of his or her citizenship status. One of the most prominent examples of this "ethical cosmopolitanism" is the Universal Declaration of Human Rights. It stipulates that human rights are universal (that is, they apply everywhere), indivisible (that is, political and civil rights cannot be separated from social and cultural rights), and inalienable (that is, they cannot be denied to any human being and should not be transferable or saleable).

Advocates of ethical standpoints that lie between the described extremes of "nationalism" and "cosmopolitanism" argue that just because certain moral principles are not completely enforceable at the international level, or are not embraced by other countries, a state cannot deny all ethical duties toward noncitizens. They argue that a strict ethical cosmopolitanism (for example, the Universal Declaration of Human Rights) is equally problematic because it clashes with anticosmopolitan institutions, such as states, in the real world. ${ }^{53}$ In other words, where nationstates are the guarantors of cosmopolitan rights, there is a natural tendency toward friction and conflict between the rights of citizens and noncitizens. For these and many more reasons, few people subscribe to any of the two extreme views (just as few people advocate a strictly consequentialist or minimally consequentialist position), but support a position of what may be called "moderate cosmopolitanism," which incorporates elements of both nationalism and cosmopolitanism. For example, Beitz suggests that a moderately strong cosmopolitan view would in-

51. Caney 1998, 32.

52. See, for example, Morgenthau 1951.

53. O’Neill 2000. 
clude the duty to pursue cosmopolitan goals with an upper boundary on the associated cost, with the upper boundary defining the degree of priority that a government accords to the interests of its citizens. ${ }^{54}$

Just as it is difficult to identify and ethically justify the appropriate degree of consequentialism, it is no easy task to justify a specific degree of moral standing for noncitizens. ${ }^{55}$ Again, we do not want to argue in favor of a particular moral standing, but want to point out that the way in which consequentialism should influence the design of a labor immigration program critically depends on what degree of moral standing the policymaker extends to noncitizens.

We conclude this section by summarizing the main arguments with the help of Figure $3 .^{56}$ The figure makes clear that the role of consequences in the design of labor immigration policy depends on the degree of consequentialism and the degree of moral standing extended to noncitizens. Together, they constitute an "ethical framework" for the evaluation of labor immigration policy.

\section{What Are the Implications for the Design of Labor Immigration Programs?}

This section discusses the implications of the four "most extreme" ethical standpoints shown in Figure 3 (rights-based nationalism, consequentialist nationalism, rights-based cosmopolitanism, and consequentialist cosmopolitanism) for the design of labor immigration policy. The three key policy parameters to consider in this exercise are the number of migrant workers to be admitted, the selection of migrant workers, and the bundle of rights extended to the admitted workers.

\section{Consequentialist Nationalism}

Consequentialist nationalism suggests that the desirable values of the three policy parameters be primarily determined by an assessment of their impact on (suitably weighted) economic efficiency, distribution, and national identity in the receiving country.

This means that the number of foreign workers admitted is essentially a centrally planned variable, determined by solving a maximization problem-a procedure widely known as "manpower planning." The inherent problem in manpower

54. Beitz 1983.

55. For discussions, see Beitz 1983; Goodin 1988; Shue 1988; Nussbaum et al. 1996; Caney 1998; and O'Neill 2000.

56. To avoid confusion between Table 1 and Figure 3, it is worth recalling that an ethical framework serves to assign weights to the various outcome parameters in Table 1. There is, however, no direct correspondence between the dimensions of Table 1 and Figure 3, as the axes in Table 1 are not meant to capture a spectrum of a single dimension (as in Figure 3), but are simply used to organize the list of outcome parameters. 


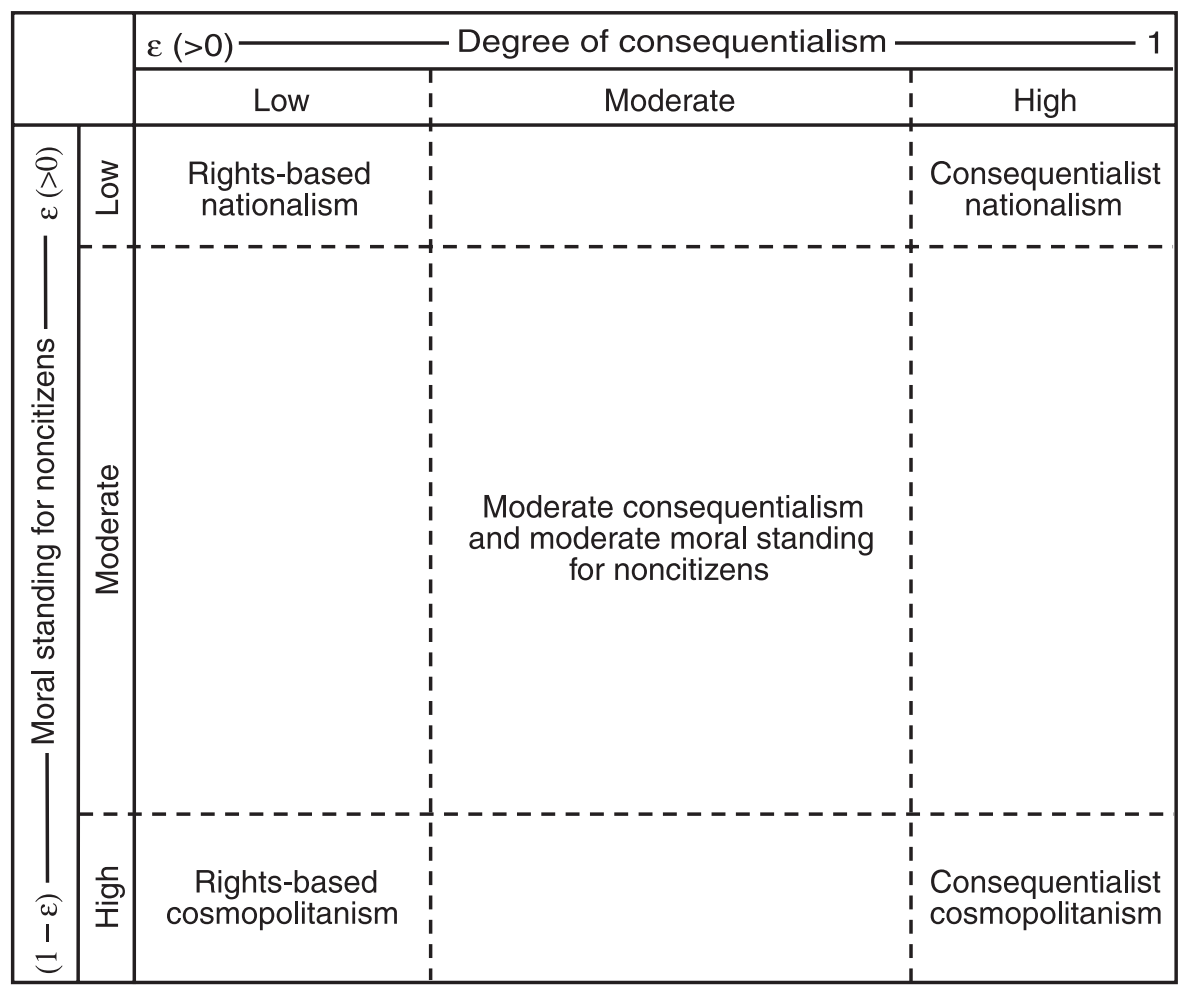

FIGURE 3. Examples of ethical frameworks ("ethical space”)

planning is, of course, the almost inevitable controversies and debates surrounding the policymaker's impact studies. For example, some have suggested that, in many cases, the alleged "need" for foreign workers is really only a reflection of employers' preferences for cheap labor.

With regard to the mechanism for the selection of foreign workers, countries whose national identity is based on an ethnic concept of nationhood (such as Germany and Israel) or that assign great importance to cultural homogeneity (such as Japan and Korea) will choose a selection mechanism that favors foreign workers who share some ethnic or cultural characteristics with the citizen population (hence the "laws of return" operative in Germany and Israel). On the other hand, where economic efficiency and distribution are given significant weights, selection is likely to be based on criteria such as skill and, more generally, on the potential for making a positive contribution to the receiving country's economy without causing too many costs for citizen workers. In practice, most countries select foreign workers based on a number of criteria, using — either explicitly or implicitly — a "points" system. For example, Canada admits "skilled migrants" who score at least 70 out of 100 points on a test that awards points based on age, occupation (to be carried 
out in Canada), education/training, arranged employment, work experience, language ability, a demographic factor (as set by the Canadian government), and the existence (or otherwise) of close relatives in Canada.

Turning to the rights extended to the admitted foreign workers, an extreme argument based on consequentialist nationalism would be that because noncitizens are accorded only a minimal degree of moral standing, the receiving country has no duty or mandate to recognize even their most basic rights. In practice, such arrangements are not as uncommon as one may think (or hope), especially in the case of foreign workers in domestic services (maids, cooks, gardeners, and so on). For example, in Kuwait, foreign domestic workers are not subject to any labor law and therefore enjoy little legal protection. Another group of migrant workers with generally small bundles of rights is illegal migrant workers. Importantly, public opinion often demands even fewer rights for these workers than policymakers are willing to offer. ${ }^{57}$

The most difficult labor immigration policy questions based on consequentialist nationalism concern the assignment of weights to (the often negatively correlated) economic efficiency, distribution, and national identity. Indeed, many countries' national immigration debates have evolved around the perceived negative correlation between economic efficiency (commonly articulated as the "economic need for migrant workers") and income distribution (commonly expressed as the "adverse impact of immigration on competing native workers"). It is important to recall that while an ethical framework of consequentialist nationalism requires policies to be derived from an analysis of the impact of labor immigration on economic efficiency, distribution, and national identity, it is silent on the actual distribution of weights among these three outcome parameters.

\section{Rights-Based Nationalism}

As discussed earlier in this article, the main challenge of any rights-based approach is to decide which and whose rights should be given priority. Thus, one may identify at least two different kinds of rights-based nationalism, depending on whether priority is given to native workers' rights to preferential access to the national labor market ("worker-rights-based nationalism") or to native employers' rights to freedom of contract with the employees (both citizen and noncitizen) of their choice ("employer-rights-based nationalism").

Under worker-rights-based nationalism, the number of foreign workers admitted is likely to be smaller than that under consequentialist nationalism, as the employment of foreign workers will be largely independent of economic efficiency

57. For example, in November 1994, Californian voters passed Proposition 187 (also known as the "Save our State Initiative"), which would have made undocumented immigrants ineligible for public social services, public health services (except for events defined as emergencies under federal law), and public education at elementary, secondary, and postsecondary levels. In 1998, a federal judge ruled that most aspects of Proposition 187 were unconstitutional and it thus never came into effect. 
and will only be tolerated if and only if it does not adversely affect the economic security of individual native workers. Similarly, to minimize competition with native workers, the type (for example, the skill levels) of the admitted foreign workers will be complementary, and the employment-related rights (such as the right to minimum wage) accorded to them will be similar to those of native workers.

Under employer-rights-based nationalism, the number, type, and rights accorded to foreign workers are essentially determined by native employers. In this case, the number of admitted foreign workers is likely to be greater than those admitted under both worker-rights-based nationalism and consequentialist nationalism. The primary reason is that employer-rights-based nationalism entitles native employers, in their employment decisions, to pay only limited attention to the consequences for the rights of individual native workers, and to largely ignore the externalities or unintended consequences of their actions for the community as a whole.

It may be argued that a policy that protects citizen employers' rights to employ as many noncitizen workers as they want to is akin to surrendering the state's sovereignty of border control to the employers. On the face of it, one may expect this to happen very rarely in practice. However, the widely observed policy of "benign neglect" over the issue of illegal immigration is, in effect, based on an ethical framework of employer-rights-based nationalism. A much-discussed example of such "benign indifference" is U.S. policy toward undocumented workers in agriculture, where internal and border enforcement efforts have been systematically relaxed during periods of high labor demand. ${ }^{58}$

\section{Consequentialist Cosmopolitanism}

Consequentialist cosmopolitanism requires labor immigration policies to be informed by the outcomes for (rather than the rights of) migrants and nonemigrant citizens (of both sending and receiving countries). If these outcomes are positive (for example, providing significant income gains for migrants, remittances for the sending country, and so on) and outweigh the potentially reduced net benefits for citizens, the number of admitted foreign workers under a cosmopolitan position is likely to be higher than that under a position with a low degree of moral standing for noncitizens. In fact, it could be argued that if economic efficiency and distribution were the only outcome parameters, consequentialist cosmopolitanism would require open borders, as the free flow of labor increases world welfare and decreases global inequality (among workers and among capital owners). Hamilton and Whalley calculate the magnitude of the global efficiency gain from free international labor migration and conclude that, depending on the prevailing elasticities of substitution, the potential gain exceeds worldwide GNP in most cases. ${ }^{59}$

58. Hanson and Spilimbergo 2001.

59. Hamilton and Whalley 1984. 
Global efficiency gains also constitute one of the main arguments used in Carens's well-known statement of the case for open borders. ${ }^{60}$

Regarding the selection of foreign workers under consequentialist cosmopolitanism, one could imagine a points system that, in contrast to the system implied by consequentialist nationalism, includes criteria ensuring that the interests of both migrants and nonemigrants are taken account of. For example, migrants could be selected based on "need," that is, among all those satisfying all other criteria, only the poorest applicants are admitted. Alternatively, in countries that assign a lot of weight to ethnic diversity or distribution and equality of opportunity among noncitizen applicants, the selection mechanism may involve a lottery, as in the American "Diversity Immigrant Visa Lottery Program."

Turning to the desirable bundle of rights for migrant workers, consequentialist cosmopolitanism requires that the bundle benefits citizens of the receiving country and sending country alike, as well as migrant workers themselves. In this context, one of the trickiest but arguably most important (as well as sensitive) questions is: What bundle of rights is in the best interest of migrant workers? Consequentialist cosmopolitanism draws attention to the important, but frequently overlooked, insight that more rights may not always be associated with "better" outcomes for migrant workers.

Consider, for example, the case of migrant workers who do not enjoy the same employment-related rights as citizens in the receiving country. Suppose that the migrant workers' wage is lower than what the citizens doing the same job receive, but is much higher than what they would earn in their country of origin. Further suppose that the migrant workers would not be employed if the native employer were somehow compelled to pay everyone equal pay for equal work. In contrast to rights-based cosmopolitanism (see below), consequentialist cosmopolitanism would tolerate (or even recommend) the described arrangement, if the improvement in the migrant workers' welfare from their employment under the condition of "unequal rights" is larger than that from a reduction of the "rights differential" between citizens and migrant workers (at the cost of reducing the chance of employment for the migrants). Within this normative framework, insisting on granting certain rights to migrant workers (for example, equal pay for equal work) would be unethical, as it makes migrant workers "worse off" in terms of their economic situation (and, possibly, also in terms of their bundle of rights). ${ }^{61}$

\section{Rights-Based Cosmopolitanism}

Under rights-based cosmopolitanism, the policy imperative is to protect the individual rights of citizens, noncitizens, and migrants. Again, as in the case of rights-

60. Carens 1987.

61. Of course, a migrant worker with fewer rights than his or her native coworker may still enjoy more rights than in his or her country of origin! 
based nationalism, the two critical questions concern, first, the hierarchy between potentially conflicting rights, and second, the number and the scope of rights to be recognized and protected by the state. However, because the right to freedom of contract is likely to be included in any system of rights (even in what Nozick calls a "minimal state"), one may expect rights-based cosmopolitanism to result in a greater number of admitted foreign workers than consequentialist cosmopolitanism. In fact, Carens argues_-drawing on Nozick's theory (which, when applied globally, qualifies as rights-based cosmopolitanism) — that restrictions on people's movement are only ethically permissible if contractually agreed upon. ${ }^{62}$

Similarly, with regard to the desirable selection mechanism, much depends on the number and priority of certain rights. For example, rights-based cosmopolitanism can suggest that citizen employers be allowed to employ foreign workers who possess the qualities that they prefer, and that foreign as well as native workers be given the opportunity to compete for jobs on a "level playing field." The freedom of movement and employment within the EU may be cited as a case in point.

As interpreted and advocated by most nongovernmental organizations (NGOs) and international organizations concerned with workers' rights, such as the International Labour Organization (ILO), rights-based cosmopolitanism can be seen to imply that any arrangement allowing for discrimination in bundles of basic rights across individuals is morally wrong. This common interpretation of rights-based cosmopolitanism overlooks, however, the fact that protecting migrant workers' rights also implies respecting their right to self-ownership and freedom of contract (and thus their right to waive/transfer/sell their rights). In other words, rights-based cosmopolitanism not only requires that migrant workers be given as many rights as the receiving country could possibly tolerate, but also that migrant workers be given the right to determine their own fate (in an environment of full information). It thus appears as though rights-based cosmopolitanism pits the argument for protection against the argument for self-ownership and alienability of rights. This, unfortunately, is rarely acknowledged.

\section{What Ethical Guidelines for the Design of Labor Immigration Policies?}

The discussion in the previous section should be seen as a first attempt to apply and work out the implications of some of the major ethical frameworks for the design of labor immigration policy. While some may not agree with the particular way in which we have drawn implications for labor immigration policy from each ethical framework, we hope that our discussion has at least shown that different frameworks can lead to sometimes radically different policy implications. But given the large set of different ethical frameworks in Figure 3, what does our discussion 
of the ethical issues tell us about the most desirable design of labor immigration policy?

Our approach to answering this question involves three steps. First, we make the case for the adoption of a combination of "realistic" and "idealistic" approaches to the ethics of labor immigration policy. We argue that this, in turn, implies the adoption of an ethical framework within the ethical subspace of moderate consequentialism and moderate moral standing for noncitizens (where "moderate" indicates the rejection of extreme positions along the border of the "ethical space" in Figure 3, rather than a specification of the ethical framework located in the perfect center of Figure 3). Second, we propose criteria that should guide national policymakers in their choice and application of a framework within that space. Finally, we briefly discuss some of the implications of the identified "ethical guidelines" for the design of labor immigration programs in practice.

\section{The Need for Moderate Consequentialism and Moderate Moral Standing for Noncitizens}

Our argument begins with the distinction between what Carens calls the "realistic" and "idealistic" approaches to morality. ${ }^{63}$ The "realistic approach" is firmly based on existing realities and stresses the importance of avoiding too big of discrepancies between the "ought" and the "can." On the other hand, the "idealistic approach" is less constrained by considerations of practicality and focuses only on what "ought to be," regardless of whether or not the implied policies are currently feasible. As Carens suggests, there is no single most "correct" starting point for theoretical reflection in the ethical discourse on immigration. ${ }^{64}$ However, if the objective of the ethical discourse is to yield practical policy implications (as it is in this article), there is a strong argument to be made for adopting a combination of both approaches. On the one hand, idealistic considerations are needed to "break new ground" in thinking about ethics and public policies. On the other hand, if the discussion is to yield any practical policy implications, there must be a significant realistic component. King makes the eminently sensible point along this line that "to ask people to accept policies which threaten to lower their own well-being sharply in the name of some abstract moral principle is clearly impracticable." 65

A realistic approach suggests that a desirable ethical framework for labor immigration policy needs to be much less cosmopolitan, and significantly more consequentialist than currently suggested by the highly rights-based and cosmopolitan ethical framework advocated by most international organizations and NGOs (see,

63. Carens 1996.

64. Ibid.

65. King 1983, 533. 
for example, the principles manifested in the ILO Migrant Worker Conventions or in the UN Treaty on Migrant Workers).

This approach starts from the recognition that, with very few exceptions (such as the EU, whose member-states have collectively decided to grant each other's citizens freedom of movement within the EU), labor immigration policy is being made at the national level. ${ }^{66}$ If one accepts that citizenship is a meaningful concept in a world of sovereign and self-determining nation-states, it follows that one needs to also accept that one cannot place unrealistic demands on national policymakers, such as equal treatment of citizens and noncitizens (where "unrealistic" is understood in the sense of being unachievable).

Furthermore, although we have not discussed the ethical framework underlying any particular country's labor immigration programs in any detail (something that is beyond the scope of this article), it may, nevertheless, be argued that many of the existing national labor immigration programs are based on an ethical framework that comes close to consequentialist nationalism - that is, a relatively low moral standing for noncitizens and relatively high weights assigned to economic efficiency, distribution, and national identity (rather than citizens' rights) as policy outcome parameters.

This preference of national policymakers - for a high degree of consequentialism and a relatively low degree of moral standing for noncitizens - is reflected in, and the major explanation for, the low numbers of ratification of the two ILO conventions and the UN treaty on migrant workers, all of which are based on an ethical framework of rights-based cosmopolitanism. As shown in Tables 2 and 3, the numbers of ratification of these international legal instruments have been disappointing — both in absolute terms (that is, considering the total number of ILO and UN member-states) and in relative terms (that is, compared to the number of ratifications of other major ILO conventions and UN human rights treaties). Importantly, the few countries that have ratified international migrant worker conventions are predominantly migrant-sending, rather than migrant-receiving, countries. ${ }^{67}$

In addition to being more realistic than the highly rights-based approach behind the above-mentioned conventions, a more than minimally consequentialist ethical

66. Note that, while there have been bilateral migration agreements-such as the Bracero program between the United States and Mexico (1942-64) and the Gastarbeiter programs between Germany and Italy, Greece, Spain, Turkey, and the former Yugoslavia (1955-73) - the most important decisions in the design and operation of these guest worker programs were still made by national policymakers in the receiving countries. Furthermore, the currently existing regional consultative processes on international labor migration are all informal and nonbinding. See Klekowski 2001.

67. As of May 2003, the UN's International Convention on the Protection of All Migrant Workers and Members of Their Families has been ratified by Azerbaijan (1999), Belize (2001), Bolivia (2000), Bosnia and Herzegovina (1996), Cape Verde (1997), Colombia (1995), Ecuador (2002), Egypt (1993), El Salvador (2003), Ghana (2000), Guatemala (2003), Guinea (2000), Mexico (1999), Morocco (1993), the Philippines (1995), Senegal (1999), Seychelles (1994), Sri Lanka (1996), Tajikistan (2002), Uganda (1995), and Uruguay (2001). 
TABLE 2. Ratifications of ILO fundamental conventions and migrant worker conventions (as of May 2003)

\begin{tabular}{|c|c|c|c|c|c|c|c|c|c|c|}
\hline \multirow{2}{*}{$\begin{array}{l}\text { ILO conventions } \\
\begin{array}{l}\text { Convention number } \\
\text { (year) }\end{array}\end{array}$} & \multicolumn{2}{|c|}{$\begin{array}{l}\text { Freedom of } \\
\text { association } \\
\text { and } \\
\text { collective } \\
\text { bargaining }\end{array}$} & \multicolumn{2}{|c|}{$\begin{array}{l}\text { Elimination } \\
\text { of forced } \\
\text { and } \\
\text { compulsory } \\
\text { labor }\end{array}$} & \multicolumn{2}{|c|}{$\begin{array}{l}\text { Elimination of } \\
\text { discrimination } \\
\text { in respect of } \\
\text { employment } \\
\text { and } \\
\text { occupation }\end{array}$} & \multicolumn{2}{|c|}{$\begin{array}{l}\text { Abolition of } \\
\text { child labor }\end{array}$} & \multicolumn{2}{|c|}{$\begin{array}{l}\text { Migrant } \\
\text { workers }\end{array}$} \\
\hline & $\begin{array}{c}87 \\
(1948)\end{array}$ & $\begin{array}{c}98 \\
(1949)\end{array}$ & $\begin{array}{c}29 \\
(1930)\end{array}$ & $\begin{array}{c}105 \\
(1957)\end{array}$ & $\begin{array}{c}100 \\
(1951)\end{array}$ & $\begin{array}{c}111 \\
(1958)\end{array}$ & $\begin{array}{c}138 \\
(1973)\end{array}$ & $\begin{array}{c}182 \\
(1999)\end{array}$ & $\begin{array}{c}97 \\
(1949)\end{array}$ & $\begin{array}{c}143 \\
(1975)\end{array}$ \\
\hline $\begin{array}{l}\text { Number of ratifications } \\
\text { by countries }\end{array}$ & 142 & 152 & 161 & 159 & 161 & 158 & 124 & 137 & 42 & 18 \\
\hline
\end{tabular}

Source: See 〈www.ilo.org $\rangle$.

framework would also be necessary to facilitate the promotion of the overall interest of migrant workers, which comprises both their rights and their economic welfare (see Table 1). Given that the promotion of migrant workers' rights and economic betterment may be negatively correlated, an extreme rights-based ethical framework would imply that no level of improvement of foreign workers' welfare would justify the restriction of some of their rights. Considering that many migrant workers migrate for economic reasons, the assignment of an only minimal weight to their economic welfare seems unlikely to be in their overall interest. At the same time, it is equally obvious that policies based on too high a degree of consequentialism, with little or no regard for even the most basic human rights of migrant workers (such as the right to bodily integrity), would be equally objec-

TABLE 3. Ratifications of principal international human rights treaties (as of May 2003)

\begin{tabular}{lccccccc}
\hline $\begin{array}{l}\text { UN human rights treaties } \\
\text { (year) }\end{array}$ & $\begin{array}{l}\text { CERD } \\
(1965)\end{array}$ & $\begin{array}{l}\text { CCPR } \\
(1966)\end{array}$ & $\begin{array}{c}\text { CESCR } \\
(1966)\end{array}$ & $\begin{array}{c}\text { CEDAW } \\
\text { (1979) }\end{array}$ & $\begin{array}{c}\text { CAT } \\
(1984)\end{array}$ & $\begin{array}{c}\text { CRC } \\
(1989)\end{array}$ & $\begin{array}{c}\text { MWC } \\
(1990)\end{array}$ \\
\hline $\begin{array}{l}\text { Number of ratifications } \\
\text { by state parties }\end{array}$ & 166 & 149 & 146 & 172 & 132 & 191 & 21 \\
\hline
\end{tabular}

Note: CERD = International Convention on the Elimination of All Forms of Racial Discrimination; CCPR = International Covenant on Civil and Political Rights; CESCR = International Covenant on Economic, Social and Cultural Rights; CEDAW = Convention on the Elimination of All Forms of Discrimination Against Women; CAT $=$ Convention Against Torture and Other Cruel, Inhuman or Degrading Treatment or Punishment; CRC $=$ Convention on the Rights of the Child; MWC = International Convention on the Protection of All Migrant Workers and Members of their Families.

Source: See 〈www.unhchr.ch〉. 
tionable within an ethical framework that purports to be concerned with the overall interest of migrant workers.

A realistic approach suggests at least two further reasons for national policymakers to protect and promote the interests of migrant workers in their countries. First, migrants who achieve better overall outcomes (in terms of both their economic welfare and rights) are less likely to be associated with crime and other "bad consequences" for the native population of the receiving country. Second, most, if not all, countries are both receivers and senders of migrant workers. Clearly, the effective protection and promotion of their citizens abroad will only be possible if receiving countries themselves offer a degree of protection to noncitizen migrant workers that is similar (at least in relative terms) to that which they expect to be accorded to their citizens abroad.

In addition to the above-mentioned reasons for protecting the interest of migrant workers based on a realistic approach, an idealistic approach requires national policymakers to give more than the minimum consideration in their policy decisions to the interests of noncitizens, based on the recognition that the employment of foreign workers is by its nature a national and international issue. This stems from the fact that, unlike the case of international trade and capital flows, the process of international labor migration creates a distinct group of individualsnamely, the migrant workers - who face an inherent risk of enjoying fewer rights and a lower degree of protection of their interests more generally than the rest of the world's population. This is because the sending country generally does not have any legal jurisdiction outside its territory, while the host country is often reluctant to assume full responsibility unless migrant workers are permanent residents or become citizens.

We therefore conclude that, given the need to adopt a combination of realistic and idealistic approaches to promote new policy ideas that have a chance of success in real life, the ethical space for the desirable design of labor immigration policy is limited to those ethical frameworks characterized by moderate degrees of consequentialism and moderate degrees of moral standing for noncitizens (see Figure 3). This implies that there are no "easy choices" in labor immigration policy: whatever the substance of the policy, national policymakers need to balance the consequences of the employment of foreign workers for the broadly-defined interests of citizens with those for the interests of migrant workers and the sending country.

\section{Consistency Criteria for the Desirable Design of Labor Immigration Policy}

Having eliminated the extreme ethical frameworks in Figure 3, we are still left with a large (in fact infinitely large) set of potentially desirable ethical frameworks (within the space of moderate consequentialism and moderate moral standing for noncitizens). This section explores whether we can say anything more concrete about the desirable design of labor immigration policy. 
We begin by recognizing the significant contextual differences that exist between different countries. These differences are manifested, for example, in differences in the level of economic development, culture, international relations with the migrant-sending countries and the world community as a whole, the role and power of the judiciary, and, perhaps most importantly, the actual capacity of the state to act and implement certain policies. ${ }^{68}$

Given the sovereignty and self-determination of nation-states, these contextual differences suggest that there is unlikely to be a single ethical framework and corresponding labor immigration policy that can be identified as the most desirable one for all countries. This implies that, rather than looking for a "one-size-fits-all" ethical framework and labor immigration policy, we can only aim to formulate criteria that guide national policymakers in the choice of an ethical framework and in the application of the chosen framework in formulating labor immigration policy.

The criteria that we propose are based on the idea that a desirable labor immigration policy needs to be logically derived (criterion of "consistency in application") from an internally consistent ethical framework (criterion of "internal consistency").

The criterion of consistency in application requires three things. First, there needs to be a comprehensive discussion of the consequences of international labor migration for all parties concerned. These discussions would need to go significantly beyond existing debates in most countries (especially outside the United States and the EU, where most of the research has been carried out). Much more research and discussion would be particularly required in areas that have so far received only little attention (see the discussion above in the second section).

Second, a country's labor immigration policies must be logically derived from the underlying ethical framework. For example, if the country's chosen ethical framework was highly cosmopolitan and egalitarian, a policy of giving migrant workers with certain nationalities preferential treatment over workers with other nationalities would be inconsistent with the underlying ethical framework and thus inadmissible.

Third, at any given point in time, the decisions on the three policy parameters (number, selection, and rights of migrant workers) need to be consistently based on one and the same ethical standpoint. This excludes, for example, a policy combination of severely restricting the rights of migrant workers based on an ethical framework that is highly consequentialist and nationalistic on the one hand, while at the same time allowing a relatively free inflow and employment of foreign workers justified by an underlying ethical framework that is highly consequentialist and cosmopolitan, on the other hand. ${ }^{69}$

68. For a discussion of the ethical obligations of weak states, see, for example, O'Neill 2000 and 2002.

69. It is important to note, however, that such a combination of policy parameters is not necessarily an ethically impermissible or undesirable policy. But it is certainly so, if the decisions on the two parameters (number and rights of migrant workers) are based on two different ethical frameworks. 
The criterion of internal consistency of the chosen ethical framework requires that the reasons for deciding on a certain degree of consequentialism must not be in conflict with the reasons for deciding on the degree of moral standing accorded to noncitizens.

For example, decisions on the degrees of consequentialism and moral standing for noncitizens may be based on a specific stance in the now long-standing debate between "individualists" and "communitarians." 70 An individualistic standpointthat is, a belief in the priority of the rights of an individual over the "common good" of the community-generally implies a minimally consequentialist position, while a communitarian view would suggest a high degree of consequentialism. At the same time, individualism has been interpreted to suggest that ethical principles are universally generalizable ("ethical universalism") — that is, that they are independent of the community of which the individual is a part. In contrast, a communitarian point of view may be interpreted as advocating "ethical relativism," which implies that morality critically depends on, and varies with, the community under consideration. It may thus be argued that an individualistic standpoint would suggest a relatively low degree of consequentialism and a high degree of moral standing for noncitizens, while a communitarian view may be interpreted to imply a higher degree of consequentialism with a lower degree of moral standing for individuals outside the community. Deciding on other combinations of consequentialism and moral standing for noncitizens-for example, the combination of a high degree of consequentialism and a high degree of moral standing for noncitizens-would violate the criterion of internal consistency (if the reasons for making these decisions stem from a stance in the individualism versus communitarianism debate).

\section{Policy Implications}

In order to translate the ethical guidelines for labor immigration policy identified in the previous two subsections into policy practice, we propose to design new types of temporary foreign worker programs that differ in at least two major ways from most of the major past and existing temporary foreign worker programs, ${ }^{71}$ and from the policies implied by some of the existing international migrant worker conventions.

First, rather than primarily benefiting a relatively small group of citizens (that is, employers of foreign workers) within the migrant-receiving country (as has been the case with many past and existing temporary foreign worker programs),

70. See, for example, Avineri and de-Shalit 1992; and Mulhall and Swift 1992.

71. For discussions of the potential problems and alleged "failure" of past programs, see, for example, Martin and Teitelbaum 2001; and Martin 2000. For the counterargument and a preliminary attempt to formulate basic principles for making temporary foreign worker programs work, see Ruhs 2003. 
the programs that we propose are designed to more actively promote the interests of migrants and sending countries, as well as those of all citizens of the receiving country. Second, rather than insisting on a very comprehensive set of rights for migrant workers (as does the UN Treaty on Migrant Workers), the programs that we have in mind would focus on a list of core rights for migrant workers, which are transparent, monitored, and effectively enforced. A related point is that, as long as the underlying ethical framework remains within the ethical subspace of moderate consequentialism and moderate moral standing for noncitizens, the detailed design of such programs could be highly country-specific.

For example, the necessary safeguards against the potential exploitation of foreign workers must include policies that avoid a situation where migrant workers are tied and thus effectively sold to employers who assume almost full control over their purchased "property." This may be achieved by giving foreign workers at least some freedom of employment within specific sectors or occupations of the host country's labor market (which are likely to vary by country and time period). Similarly, foreign workers need to be offered protection with regard to employment conditions, especially those pertaining to working hours and safety at work. This would also ensure that foreign workers do not compete with native workers in terms of non-wage-related employment conditions, such as accepting overtime without pay and lower safety standards at work.

One particular area of concern to national policymakers should be to ensure that foreign workers join temporary foreign worker programs based on a wellinformed assessment of the consequences of this decision for their welfare and rights. Among other things, this necessitates transparency in the operation of the program and "truth in advertising," which entails strict enforcement against employers or recruitment agents who recruit and employ foreign workers based on the provision of misleading information about employment and living conditions in the receiving country.

It should also be recognized at the stage of policy design that some admitted foreign workers may seek permission to remain in the host country on a permanent basis and to bring their families into their country of employment (if that right has not already been granted under the temporary foreign worker program). This means that the implementation of any temporary foreign worker program must also include mechanisms and rules for transfer into different and "better" programs that grant foreign workers permanent residence status (and possibly citizenship) and the right to family reunion. Possibly depending on, inter alia, the share of foreign workers in the total population, these rules for transfer are likely to differ both between different countries and across time periods within a single country.

At the same time, temporary foreign worker programs that are based on an ethical framework characterized by moderate degrees of consequentialism and moral standing for noncitizens would need to deny migrant workers some of the rights that are generally granted to citizens and permanent residents of the host country. 
Examples of migrant workers' rights that would need to be restricted include the right to free choice of employment in the host country's labor market and, more obviously, the right to remain employed in the host country following the expiration of the work permit. The restriction of these rights is necessary to make the program beneficial to the host country in the first place by, for example, protecting the employment of citizens in certain sectors, and by facilitating the voluntary or forced return home of foreign workers whose work permits have expired and who have failed to upgrade into different, more permanent immigration programs.

Some restrictions of the rights of foreign workers may also be necessary to make sure that the sending country benefits from such programs. For example, to avoid the effective permanence of what is supposed to be temporary emigration (and the associated potential decay of remittances), and to facilitate the transfer of the skills potentially acquired by migrant workers in the host country back to the sending country, it may be necessary to issue work permits/visas that are strictly limited in time and that may not be renewed an unlimited number of times (unless the status of the migrant worker is upgraded into higher categories such as permanent residency or citizenship). The restriction of foreign workers' maximum period of employment abroad is also likely to benefit workers who still work in their home countries but seek to migrate and work abroad, as longer stays of the workers currently abroad naturally make it more difficult for outsiders to gain access to a given foreign labor market.

If implemented successfully, temporary foreign worker programs that are designed along the lines described above would generate more tangible and sustainable benefits for migrant workers and sending countries than current and past programs have done. At the same time, they would offer host countries considerable room for maximizing the positive consequences of labor immigration (such as the alleviation of labor shortages in times of rapid economic growth and tight labor markets) and for protecting the interests and rights of all of their citizens (such as a citizen worker's rights to preferential access to the national labor market and the right to share in the economic benefits created by the program). One may therefore reasonably expect that the advocacy and implementation of such programs may significantly raise the global number of international migrant workers. Given that the current degree of international labor market integration is significantly lower than that of the integration of international markets for capital and commodities, the potential economic benefits from liberalizing international labor flows (through, as we suggest, new and expanded temporary foreign worker programs) significantly exceed those from further liberalizing international trade and capital flows. ${ }^{72}$ 


\section{Conclusion}

Because of the general reluctance and apparent inability among the participants in labor immigration debates to explicitly state, justify, and critically discuss the ethical underpinnings of their arguments, labor immigration debates have been largely carried out in a very confused way. As a result, people frequently talk at crosspurposes without any hope of appreciating and critically discussing competing points of view.

In an effort to help better organize the general discussion on international labor migration, this article has tried to identify and disentangle the fundamental ethical questions relevant to the evaluation and design of labor immigration policy.

We suggest that participants in labor immigration debates need to first acknowledge the role of migrant workers' rights as a key policy parameter in international labor migration and then engage in three distinct and separate discussions about: (1) the consequences of international labor migration for the receiving country, sending country, and migrants; (2) the degree of consequentialism employed in policy design and the moral standing accorded to noncitizens; and (3) the implications of the resulting "ethical framework" for the design of labor immigration policy.

Our discussion of the potential ethical guidelines for the design of labor immigration policy concludes that, if one accepts the need for adopting a combination of realistic and idealistic approaches to advance new policy ideas that have a chance of success, there is a case to be made for the rejection of extreme ethical frameworks within the ethical space of consequentialism and moral standing for noncitizens.

We further argue that the sovereignty and significant contextual differences that exist between different nation-states suggest that there is unlikely to be a "onesize-fits-all" ethical framework and labor immigration policy. We thus propose criteria that should guide national policymakers in the process of choosing and applying a framework within the ethical subspace of moderate consequentialism and moderate moral standing for noncitizens. The criteria that we propose are based on the idea that a desirable labor immigration policy needs to be logically derived (criterion of "consistency in application") from an internally consistent ethical framework (criterion of "internal consistency").

Finally, based on the "ethical guidelines" for the design of labor immigration programs identified in our analysis, we make the "ethical case" for new types of temporary foreign worker programs that are designed to more actively promote the interests of migrant workers and sending countries than most current and past guest worker policies have done. We argue that such new programs need to more clearly define, and more effectively enforce, certain core rights of migrant workers.

To be sure, the ethical questions that we ask in this article are exceedingly difficult to answer. These questions are politically sensitive and, perhaps more importantly, require the participants in labor immigration debates to question the 
(sometimes very personal) ethical values and convictions underlying their arguments. However, without a more honest discussion that does not shy away from ethical questions, the issue of international labor migration will remain the "soft underbelly" of globalization.

\section{References}

Adelman, Irma, and J. Edward Taylor. 1990. Is Structural Adjustment with a Human Face Possible? The Case of Mexico. Journal of Development Studies 26 (3):387-407.

Anderson, Benedict. 1983. Imagined Communities: Reflections on the Origin and Spread of Nationalism. London: Verso.

Avineri, Shlomo, and Avner de-Shalit, eds. 1992. Communitarianism and Individualism. Oxford: Oxford University Press.

Bean, Frank D., et al. 1988. Undocumented Mexican Immigrants and the Earnings of Other Workers in the United States. Demography 25 (1):35-52.

Beitz, Charles. 1983. Cosmopolitan Ideals and National Sentiment. The Journal of Philosophy 80 (10):591-600.

Borjas, George J. 1995. The Economic Benefits from Immigration. Journal of Economic Perspectives $9(2): 3-22$.

- 2001. Does Immigration Grease the Wheels of the Labour Market? Brookings Papers on Economic Activity 1:69-133.

Borjas, George J., Richard B. Freeman, Lawrence F. Katz. 1997. How Much Do Immigration and Trade Affect Labour Market Outcomes? Brookings Papers on Economic Activity 1:1-90.

Caney, Simon. 1998. Cosmopolitanism, Realism and the National Interest. In The Legal and Moral Aspects of International Trade, edited by Geraint Parry, Asif Qureshi, and Hillel Steiner, 29-44. London: Routledge.

Card, David. 1990. The Impact of the Mariel Boatlift on the Miami Labor Market. Industrial and Labor Relations Review 43 (2):245-57.

- 2001. Immigrant Inflows, Native Outflows, and the Local Labour Market Impacts of Higher Immigration. Journal of Labor Economics 19 (1):22-64.

Carens, Joseph H. 1987. Aliens and Citizens: The Case for Open Borders. The Review of Politics 49 (2):251-73.

- 1996. Realistic and Idealistic Approaches to the Ethics of Migration. International Migration Review 30 (1):156-70.

Chandavarkar, Anand G. 1980. Use of Migrants' Remittances in Labour-Exporting Countries. Finance \& Development 17 (2):36-39.

Chang, Ha-Joon. 2002. Breaking the Mould: An Institutionalist Political Economy Alternative to the Neo-liberal Theory of the Market and the State. Cambridge Journal of Economics 26 (5):539-59.

Chang, Ha-Joon, and Robert Rowthorn. 1995. Introduction. In The Role of the State in Economic Change, edited by Ha-Joon Chang and Robert Rowthorn, 1-27. Oxford: Clarendon.

Cohen, Marshall. 1984. Moral Skepticism and International Relations. Philosophy and Public Affairs 13 (4):299-346.

Davis, Donald R., and David E. Weinstein. 2002. Technological Superiority and the Losses from Migration. Working Paper 8971. Cambridge, Mass.: National Bureau of Economic Research.

Desai, Mihir, Devesh Kapur, and John McHale. 2001. The Fiscal Impact of the Brain Drain: Indian Emigration to the U.S. Paper presented at the Third Annual NBER-NCAER Conference, December, Neemrana Fort Palace, India.

Espenshade, Thomas J., and Vanessa King. 1994. State and Local Fiscal Impacts of United States Immigrants: Evidence from New Jersey. Population Research and Policy Review 13 (3):225-56. 
Filer, Randall K. 1992. The Effects of Immigrant Arrivals on Migratory Patterns of Native Workers. In Immigration and the Workforce: Economic Consequences for the United States and Source Areas, edited by George Borjas and Richard Freeman, 245-69. Chicago: Chicago University Press.

Fitzgerald, David. 2000. Negotiating Extra-Territorial Citizenship: Mexican Migration and the Transnational Politics of Community. CCIS Monograph. San Diego: Center for Comparative Immigration Studies, University of California at San Diego.

Fix, Michael, and Jeffrey S. Passel. 1994. Immigration and Immigrants: Setting the Record Straight. Washington, D.C.: Urban Institute.

Freeman, Gary. 1995. Modes of Immigration Politics in Liberal Democratic States. International Migration Review 29 (4):881-902.

Goodin, Robert E. 1988. What Is So Special About Our Fellow Countrymen? Ethics 98 (4):663-86.

Hamilton, Bob, and John Whalley. 1984. Efficiency and Distributional Implications of Global Restrictions on Labour Mobility: Calculations and Policy Implications. Journal of Development Economics $14(1-2): 61-75$.

Hanson, Gordon, and Antonio Spilimbergo. 2001. Political Economy, Sectoral Shocks, and Border Enforcement. Canadian Journal of Economics 34 (3):612-38.

Hausman, Daniel M., and Michael S. McPherson. 1993. Taking Ethics Seriously: Economics and Contemporary Moral Philosophy. Journal of Economic Literature 31 (2):671-731.

Hunt, Jennifer. 1992. The Impact of the 1962 Repatriates from Algeria on the French Labour Market. Industrial and Labour Relations Review 45 (3):556-72.

Jacobsen, David. 1996. Rights Across Borders: Immigration and the Decline of Citizenship. Baltimore, Md.: Johns Hopkins University Press.

Joppke, Christian. 1998. Why Liberal States Accept Unwanted Immigration. World Politics 50 (2): 266-93.

Jordens, Ann-Mari. 1997. Alien to Citizen: Settling Migrants in Australia, 1945-75. St. Leonards, Australia: Allen \& Unwin.

Kindleberger, Charles. 1967. Europe's Postwar Growth: The Role of Labour Supply. Cambridge, Mass.: Harvard University Press.

King, Timothy. 1983. Immigration from Developing Countries: Some Philosophical Issues. Ethics 93 (3):525-36.

Klekowski, Amanda. 2001. The Role of Regional Consultative Processes in Managing International Migration. Migration Research Series 3. Geneva: International Organization for Migration (IOM).

Kymlicka, Will. 2002. Contemporary Political Philosophy: An Introduction. 2d ed. Oxford: Oxford University Press.

Martin, Philip. 2000. Guest Worker Programs for the 21st Century. Backgrounder, April, Washington, D.C.: Center for Immigration Studies.

Martin, Philip, and Martin Teitelbaum. 2001. The Mirage of Mexican Guest Workers. Foreign Affairs 80 (6):117-31.

Morgenthau, Hans. 1951. In Defense of the National Interest: A Critical Examination of American Foreign Policy. New York: Knopf.

Mulhall, Stephen, and Adam Swift. 1992. Liberals and Communitarians. Oxford: Blackwell Publishers.

Nayyar, Deepak. 1994. Migration, Remittances and Capital Flows: The Indian Experience. Delhi, India: Oxford University Press.

Noiriel, Gérard. 1996. The French Melting Pot: Immigration, Citizenship, and National Identity. Minneapolis: University of Minnesota Press.

Nozick, Robert. 1974. Anarchy, State and Utopia. New York: Basic Books.

Nussbaum, Martha, et al. 1996. For Love of Country: Debating the Limits of Patriotism. Boston: Beacon Press.

Nye, Joseph S. 2000. Understanding International Conflicts, 3d ed. New York: Longman.

- 2002. The American National Interest and Global Public Goods. International Affairs 78 (2): 233-44.

O’Neill, Onora. 2000. Bounds of Justice. Cambridge: Cambridge University Press. 
. 2002. Global Justice: Whose Obligations? Talk given at the launch of the Centre for the Study of Global Ethics, 23 May, Birmingham, England. Available at 〈http://www.globalethics.bham.ac.uk/ ONeill.htm $\rangle$. Accessed 20 June 2003.

Pope, David, and Glenn Withers. 1993. Do Migrants Rob Jobs? Lessons of Australian History, 18611991. Journal of Economic History 53 (4):719-42.

Rawls, John. 1985. Justice as Fairness: Political not Metaphysical. Philosophy and Public Affairs 14 (3):223-51.

Rodrik, Dani. 2002. Feasible Globalizations. Working Paper 9129. Cambridge, Mass.: National Bureau of Economic Research.

Roy, Arun S. 1997. Job Displacement Effects of Canadian Immigrants by Country of Origin and Occupation. International Migration Review 31 (1):150-61.

Ruhs, Martin. 2003. Temporary Foreign Worker Programs: Policies, Adverse Consequences, and the Need to Make Them Work. Perspectives on Labor Migration 6. International Migration Program. Geneva: International Labour Office.

Russell, Sharon. 1986. Remittances from International Migration: A Review in Perspective. World Development 14 (6):677-96.

Scheffler, Samuel, ed. 1988 Consequentialism and Its Critics. Oxford: Oxford University Press.

Schuck, Peter H. 1998. Citizens, Strangers, and In-Betweens: Essays on Immigration and Citizenship. Boulder, Colo.: Westview Press.

Sen, Amartya. 1999. Development As Freedom. Oxford: Oxford University Press.

Shue, Henry. 1988. Mediating Duties. Ethics 98 (4):687-704.

Sidgwick, Henry. 1908. The Elements of Politics, 3d ed. London: Macmillan.

Stalker, Peter. 1994. The Work of Strangers: A Survey of International Labour Migration. Geneva: International Labour Office.

Sykes, Alan. 1995. The Welfare Economics of Immigration Law. In Justice in Immigration, edited by Warren Schwartz, 158-200. Cambridge: Cambridge University Press.

Taran, Patrick. 2000. Human Rights of Migrants: Challenges of the New Decade. International Migration 38 (6):7-52.

Taylor, J. Edward. 1999. The New Economics of Labour Migration and the Role of Remittances in the Migration Process. International Migration Review 37 (1):63-88.

Taylor, J. Edward, Joaquin Arango, Graeme Hugo, Ali Kouaouci, Douglas S. Massey, and Adela Pellegrino. 1996. International Migration and National Development. Population Index 62 (2):181-212.

Trefler, Daniel. 1997. Immigrants and Natives in General Equilibrium Trade Models. Working Paper 6209. Cambridge, Mass.: National Bureau of Economic Research.

United Nations High Commissioner for Refugees (UNHCR). 2002. Refugees and Others of Concern to UNHCR, 2000 Statistical Overview. Geneva: UNHCR. Available at 〈http://unher.org〉. Accessed 20 June 2003.

United Nations Population Division (UNPOP). 2002. International Migration Report 2002 (ST/ESA/ SER.A/220). New York: UNPOP. Available at (http://www.un.org/esa/population/publications/ ittmig2002/2002ITTMIGTEXT22-11.pdf〉. Accessed 20 June 2003.

Walker, Robert, Mark Ellis, and Richard Barff. 1992. Linked Migration Systems: Immigration and Internal Labour Flows in the United States. Economic Geography 68 (3):234-48.

Watts, Julie R. 2000. An Unconventional Brotherhood: Union Support for Liberalized Immigration in Europe. CCIS Monograph. San Diego: Center for Comparative Immigration Studies, University of California at San Diego.

Weber, René, and Thomas Straubhaar. 1996. Immigration and the Public Transfer System: Some Empirical Evidence for Switzerland. Weltwirtschaftliches Archiv 132 (2):330-55.

Weinstein, Eric. 2001. Migration for the Benefit of All: Towards a New Paradigm for Migrant Labor. International Migration Paper 40. Geneva: International Labour Office (ILO).

Wright, Richard A., Mark Ellis, and Michael Reibel. 1997. The Linkage Between Immigration and Internal Migration in Large Metropolitan Areas in the United States. Economic Geography 73 (2):234-54.

Zlotnik, Hania. 1998. International Migration 1965-96: An Overview. Population and Development Review 24 (3):429-68. 